\title{
Analisis Pemilihan Media Pembelajaran Sentra IMTAQ di TK Negeri Pembina 3 Pekanbaru
}

\author{
Nopa Wilyanita \\ nwilya@gmail.com \\ STKIP Aisyiyah Riau, Indonesia \\ Utari Tri Wahyuni \\ utaritriwahyuni@gmail.com \\ STKIP Aisyiyah Riau, Indonesia
}

\begin{abstract}
This study aims to determine the selection of Imtaq center learning media that is right for children and how teachers choose learning media that are of interest to children. The subject of this study was the teacher at the center of the TK 3 Pembina 3 of Pekanbaru City. The method of this research is qualitative descriptive. The results of this study for children is to train the concentration of children, teach children faster with a relatively short time, increase the power of understanding and memory, as well as pleasant learning. As for the teacher, (1) the media used by the teacher has increased the enthusiasm of the child while studying, (2) the media applied by the teacher is good and the child can complete the activities provided by the teacher, (3) the teacher is creative in making learning media.
\end{abstract}

\begin{abstract}
Abstrak
Penelitian ini bertujuan untuk mengetahui pemilihan media pembelajaran sentra Imtaq yang tepat bagi anak dan bagaimana cara guru memilih media pembelajaran yang menarik bagi anak. Subjek penelitian ini adalah guru disentra Imtaq TK Negeri Pembina 3 Kota Pekanbaru. Metode penelitian ini adalah deskriptif kualitatif. Hasil penelitian ini untuk anak adalah Melatih konsentrasi anak, Mengajari anak lebih cepat dengan waktu relatife singkat, Menambah daya pengertian dan ingatan, serta Pembelajaran yang menyenangkan. Sedangkan untuk gurunya adalah (1) media yang digunakan oleh guru sudah meningkatkan antusias anak saat belajar, (2) media yang diterapkan oleh guru sudah baik dan anak bisa menyelesaikan kegiatan yang diberikan oleh guru,(3) guru sudah kreatif dalam pembuatan media pembelajaran.
\end{abstract}

Kata kunci : Media Pembelajaran, Sentra Imtaq 


\section{PENDAHULUAN}

\section{Latar Belakang}

Menurut Undang-Undang Nomor 20 Tahun 2003 tentang Sistem Pendidikan Nasional Pasal (1), menyatakan bahwa pembelajaran adalah proses interaksi peserta didik dengan pendidik dan sumber belajar pada suatu lingkungan belajar.

Melalui pembelajaran anak usia dini memegang peran yang penting dalam pembentukan kemampuan dan sikap belajar pada tahap yang lebih lanjut. Dengan proses pembelajaran tersebut peran guru bukan hanya semata-mata memberikan informasi, melainkan juga mengarahkan dan memberikan fasilitas belajar agar proses belajar menjadi lebih efektif.

Kegiatan pembelajaran taman kanak-kanak (TK) didesain untuk memungkinkan anak bermain, setiap kegiatan harus mencerminkan jiwa bermain anak yaitu senang dan demokratis, setiap permainan yang diberikan haruslah ada unsur pendidikan sehingga anak akan memilki kebebasan untuk mengekspresikan diri imajinasi dan kreativitas berpikirnya.

Pembelajaran yang diberikan oleh guru hendaknya direncanakan, dilaksanakan dan dikemas dalam bentuk kegiatan bermain. Agar pembelajaran tersebut menjadi menyenangkan, menggembirakan dan menarik bagi anak agar anak terlibat dalam setiap kegiatan pembelajaran. Dengan begitu anak akan aktif berinteraksi dengan berbagai benda dan orang lain dilingkungan baik secara fisik maupun secara mental.

Maka dari itu media pembelajaran yang digunakan oleh guru hendaknya memiliki unsur kreatif dan inovatif. Dengan unsur tersebut anak menarik perhatian anak, mengingat dimana usia tersebut merupakan masa yang siap merespon apa saja yang diberikan lingkungannya dibandingkan dengan menggunakan media gambar dikeratas dan diwarnai.

Menurut Arief S. Sadiman dalam (M.Fadillah, 2017:197) media pembelajaran ialah segala sesuatu yang dapat digunakan untuk menyalurkan pesan dan pengirim ke pengirim, sehingga dapat merangsang pikiran, perasaan, perhatian dan minat anak dan dengan demikian terjadilah proses belajar. Sedangkan menurut Heinich media pembelajaran adalah akal komunikasi yang digunakan dalam proses pembelajar untuk membawa informasi dari pengajar kepeserta didik.

Dapat disimpulkan bahwa media pembelajaran marupakan alat sarana perantara untuk menyampaikan materi pembelajaran, supaya materi yang diinginkan dapat tersampaikan dengan tepat, mudah, dan diterima serta dipahami sebagaimana mestinya oleh peserta didik.

Pada saat melakukan pengamatan di TK Negeri Pembina 3 Kota Pekanbaru bahwa saat memasuki kelas anak duduk dengan rapi dan tenang, ketika guru menjelaskan pembelajaran ada beberapa anak yang tidak memperhatikan guru, pada saat guru menjelaskan pembelajaran tidak ada antusias anak saat melihat media pembelajaran yang digunakan gurunya. Suasana dikelas sentra Imtaq juga kurang 
nyaman bagi anak dan sebagaian anak tampak merasa bosan saat belajar. Ketika guru memberikan tugas 11 dari 19 anak tidak bisa menyelesaikan tugasnya dengan baik, dikarenakan ada anak yang bosan dan tidak mau melanjutkan kegiatan, karena kegiatannya menggunakan media yang sudah sering digunakan oleh guru, maka mereka hanya bisa menyelesaikan setengah dari hasil kegiatan yang diberikan oleh gurunya.

Berdasarkan paparan diatas menunjukkan bahwa Dalam proses belajar ini guru masih saja sering menggunakan media pembelajaran yang terbuat dari kertas secara berulang-ulang. Hal inilah yang membuat peneliti merasa tertarik terhadap hal-hal yang berkaitan dalam Sentra Imtaq mengapa anak kurang tertarik belajar disentra Imtaq.

\section{Rumusan Masalah}

Bagaimana cara guru memilih media pembelajaran sentra imtaq yang tepat, dan menarik bagi anak di TK Negeri Pembina 3 Kota Pekanbaru?

\section{Tujuan}

Penelitian ini bertujuan untuk mengetahui pemilihan media pembelajaran sentra Imtaq yang tepat bagi anak dan bagaimana cara guru dalam mamilih media pembelajaran yang menarik bagi anak.

\section{TINJAUAN PUSTAKA}

\section{Media Pembelajaran}

Menurut Gerlach dan Ely dalam (Nizwardi dkk, 2016:2) bahwa media jika dipahami secara garis besar adalah manusia, materi, atau kejadian yang membangun kondisi, yang menyebabkan siswa mampu memperoleh pengetahuan, keterampilan, atau sikap. Dalam pengertian ini, guru, teman sebaya, buku teks, lingkungan sekolah dan luar sekolah, bagi seorang siswa merupakan media. Secara lebih khusus, pengertian media dalam proses pembelajaran cenderung diartikan sebagai alat-alat grafis, fotografi, atau elektronis untuk menangkap, memproses, dan menyusun kembali informasi visual atau verbal.

Sedangkan menurut AECT (Association of Education and Communication Tecnology) yang dikutip oleh fadlillah (2017:196) media adalah segala bentuk dan saluran yang digunakan untuk menyampaikan pesan atau informasi. Artinya dengan menggunakan media, diharapkan informasi dapat tersampaikan dengan baik, cepat dan tepat.

Harjonto mengatakan dalam (jurnal Kurnia, 4:1017) Media pengajaran dibagi dua bagian yaitu media dalam arti sempit dan media dalam arti luas. Dalam arti sempit, media pengajaran hanya meliputi media yang dapat digunakan secara efektif dalam proses pengajaran yang terencana, sedangkan dalam arti luas, media tidak hanya meliputi media komunikasi elektronik yang kompleks akan tetapi juga mencakup alat-alat sederhana seperti slide, fotogarfi, diagram dan bagan buatan guru. 
Berdasarkan teori di atas dapat disimpulan bahwa media pembelajaran merupakan segala sesuatu yang bersifat menyalurkan pesan dan dapat merangsang pikiran, dan kempampuan anak sehingga dapat mendorong terjadinya proses belajar pada diri anak. Dengan begitu penggunaan media secara kreatif akan memungkinkan anak untuk belajar lebih baik dan dapat meningkatkan kemampuan mereka sesuai dengan tujuan yang dicapao oleh pendidik.

\section{Sentra Imtaq}

Sentra berasal dari kata center yang artinya pusat. Materi yang digunakan oleh guru kepada anak melalui kegiatan-kegiatan yang sudah direncana dan perlu diorganisasikan secara teratur dan sisitematis, dan terarah, sehingga anak dapat membangun kemampuan menganalisisnya dan dapat mempunyai kemampuan mengambil kesimpulan. Sentra mengandung makna bahwa setiap kegiatan disemua sentra yang disediakan memilki titik pusat (center point), yang semuanya mengacu pada tujuan pembelajaran (Mukhtar Latif dkk. 2016:121).

Dengan pendekatan sentra dan lingkaran adalah pendekatan penyelenggaran PAUD yang berfokus pada anak yang dalam proses pembelajarannya berpusat disentra main dan saat anak dalam lingkaran dengan menggunakn jenis pijakan (scaffolding) untuk mendukung perkembangan anak, yaitu (1) pijakan lingkaran main, (2) pijakan sebelum main, (3) pijakan selama main dan (4) pijakan setelah main. Setiap pijakan mempunyai prosedur tersendiri saat pelaksanaannya, sehingga pemahaman guru pemahaman guru terhadap setiap pijakan akan membawa kegitan pembelajaran di PAUD mejadi lebih terarah, teratut dan terorganisasi.

Dimana dalam penerapan konsep sentra dan waktu lingkaran dibangun 18 sikap antara lain: mutu, ikhlas, sabar, rajin, berpikir positif, hormat, ramah, kasih sayang, rendah hati, bersih, tanggung jawab, syukur, jujur, taqwa, istikamah, khusyuk, disiplin, dan kanaah, yang akan mampun membawa anak memiliki akhlak mulia, kecerdasab jamak yang membuat anak menyeimbangkan dan mengoptimalkan penggunaan otak kiri dan kananya antara lain: kecerdasan bahasa, kecerdasan logic-matematika, kecerdasan music, kecerdasan menggunakan seluruh bagian tubuh, kecerdasan spasial, kecerdasan intrapersonal, kecerdasan alami, kecerdasan spiritual, serta delapan domain berfikir pada anak usia dini antara lain: estetik, afeksi, kognisi, bahsa, psikomotor, sosial, main pura-pura, dan pembangunan. Dimana keseluruhnya dikemas secra terpadu melalui kegiatan-kegiatan bermain pada tujuh sentra yaitu, sentra persiapan, sentra main peran, sentra sentra bahan alam, sentra imtak, sentra seni, dan sentra balok.

Sentra iman dan taqwa, tempat bermain sambil belajar untuk mengembangkan kecerdasan jamak dimana kegiatan main lebih menitikberatkan pada kegiatan keagama. Di sentra ini anak difasilitasi dengan kegiatan bermain yang memfokuskan pada pembiasaan beribadah dan mengenal huruf hijaiyah dengan cara bermain sambil belajar. Efek yang diharapkan tertanamnya perilaku akhlakul karimah, ikhlas, sabar dan senang menjalankan perintah agama (Dadan. 2016:276) 
Sentra imtaq adalah sentra yang memberikan kesempatan kepada anak pembelajaran nilai-nilai, aturan-aturan agama, sehingga anak dapat mengembangkan keimanan dan ketakwaan melalui pembelajaran sehari-hari pada kegiatan bermain anak. Dimana sentra imtaq berfokus untuk mendukung anak mengenal dan membangun konsep-konsep Al-Qur'an dan Hadis (Mukhtar Latif dkk. 2016:135).

Dari uraian diatas dapat disimpulkan bahwa Sentra Imtaq merupakan suatu sentra dimana anak dapat mengenal berbagai amalan sholeh seperti, mengetahui cara berwudu', mengenal gerakan shalat, mengetahui huruf hijaiyah, dan mengenal surat-surat pendek (juz 'amma).

\section{Gambar 2.1 Kerangka Berfikir Penelitian}

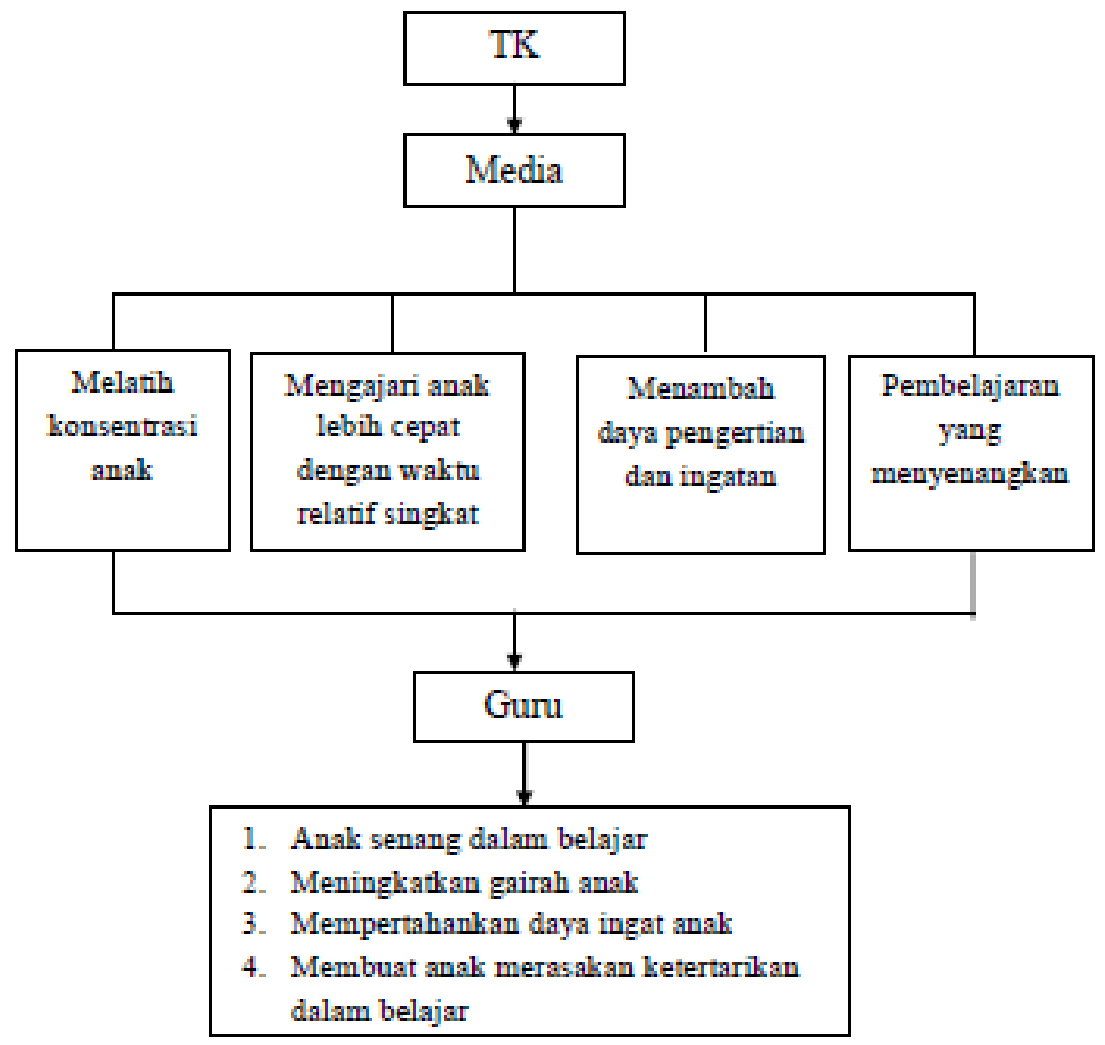

\section{METODE PENELITIAN}

Penelitian ini menggunakan pendekatan deskriptif kualitatif. Menurut Bogdan \& Taylor (dalam Iman Gunawan, 2013:82) penelitian kualitatif adalah prosedur penelitian yang menghasilkan data deskriptif berupa kata-kata tertulis atau lisan dari 
orang-orang dan berperilaku yang dapat diamati yang diarahkan pada latar dan individu secara holistic (utuh).

Adapun data penelitian ini melalui observasi, wawancara dan dokumentasi sedangkan teknik analisis datanya adalah reduksi data, penyajian data dan penarikan kesimpulan.

\section{HASIL DAN PEMBAHASAN}

\section{Hasil penelitian}

Berikut hasil penelitian yang peneliti lakukan di Kecamatan Marpoyan Damai Kota Pekanbaru. Dengan memperhatikan beberapa hal tentang "Analisis pemilih media pembelajaran sentra Imtaq di TK Negeri Pembina 3 Pekanbaru".

Berdasarkan hasil wawancara dan observasi peneliti dilapangan dibulan Juli dan Agustus diketahui bahwa secara teori tingkat pemahaman guru baik namun secara praktik hanya beberapa persen saja mereka melakukannya. Setiap imdikator atau pertanyaan dijawab oleh responden dengan jelas dan singkat.

\section{Pembahasan}

Mengajar adalah suatu yang kompleks dimana terjadinya interaksi anatara guru, anak dan alat (media pembelajaran) sebagai pelantara dalam proses pembelajaran untuk mencapai tujuan yang telah ditetepkan sebelumnya. Dimana guru sebagai pendidik harus menguasai berbagai perspektif dan strategi dan dapat mengeplikasikannya secara fleksibel, bahwa guru yang baik aialah guru yang punya alat-alat yang bisa menarik perhatian anak dan guru yang baik adalah guru yang membuat anak mampu berfikir kreatif dan imajinasinya.

Menurut Kemp dan Dayton (dalam Fadlillah,2017:197) ada beberapa manfaat media pembelajaran sebagai berikut:

1. Penyampaian materi pembelajaran dapat diseragamkan

2. Proses pembelajaran menjadi lebih menarik

3. Proses pembelajaran menjadi lebih interaktif

4. Jumlah waktu belajar mengajar dapat dikurangi

5. Kualitas belajar siswa dapat ditingkatkan

6. Proses belajar dapat terjadi dimana dan kapan saja

7. Sikap positif siswa terhadap proses belajar dapat ditingkatkan

8. Peran guru dapat berubah kearah yang lebih positif dan produktif

Menurut Gerlach dan Ely dalam (Nizwardi dkk,2016:2) bahwa media jika dipahami secara garis besar adalah manusia, materi, atau kejadian yang membangun kondisi, yang menyebabkan siswa mampu memperoleh pengetahuan, keterampilan, atau sikap.

Dapat dijelaskan bahwa proses pembelajaran proses komunikasi yang berlangsung dalam suatu sistem dan didalamnya terdapat media pembelajaran sebagai salah satu komponen sistem pembelajaran di TK.

Media pembelajaran merupakan sesuatu yang bersifat menyalurkan pesan dan dapat merangsang pikiran, perasaan dan kemauan anak sehingga dapat mendorong terjadinya proses belajar pada diri anak, dengan penggunaan media secara kreatif akan memungkinkan anak untuk belajar lebih baik dan 
meningkatkan performan mereka sesuai dengan tujuan yang ingin dicapai oleh anak. Dengan demikian pengaruh media sangat besar perannya dalam proses belajar anak, karena dengan media pembelajaran itu membantu guru dalam proses pembelajaran dan anak lebih gampang memahami pembelajaran .

Terdapat empat manfaat dari media pembelajaran pada anak usia dini disentra Imtaq yaitu:

1. Melatih konsentrasi anak

Melatih konsentrasi anak, maksudnya dengan menggunakan media pembelajaran akan membantu anak dalam belajar dan bermain dimana media itu memudahkan anak untuk mengingat objek-objek apa saja yang dilihatnya pada saat pembelajaran dikelas dan dengan media pembelajaran yang baik maka akan membantu anak dalam meningkatkan daya tangkap anak.

Hal ini dapat Peneliti jumpai disentra Imtaq TK Negeri Pembina 3 Pekanbaru, dimana pada saat guru sedang menjelaskan media pembelajaran awalnya anak antusia saat mendengarkan guru menjelaskan topik pembelajaran dan media yang akan digunakan oleh guru, anak terlihat serius dan tenang saat mendengarkannya, lalu beberapa anak mulai terganggu konsentrasinya, karena ada temannya yang ribut saat guru sedang menjelaskan topik pembelajaran.

Reaksi guru saat anak yang menganggu temannya tersebut biasanya guru memanggil anak dengan kata-kata "anak bunda sayang jangan menganggu temannya perhatikan bundanya didepan" atau dengan kata "abang ganteng dan kakak cantik" dengan kata tersebut anak langsung memperhatikan kembali gurunya yang sedang menjelaskan pembelajaran. ketika guru memasuki penjelasan tentang media yang digunakan guru, biasanya guru memberikan tepuk semangat kepada anak, agar anak tidak merasa bosan pada saat guru menjelaskan media. Guru biasanya menggunakan media kertas, plastisin, puzzle hijaiyah tergantung topik pembelajarannya. Ketika guru menjelaskan media pembelajaran anak akan terganggu lagi konsentrasinya, dimana aka nada gangguan dari temannya atau media pembelajarannya kurang menarik bagi anak.

Peneliti melihat pada saat guru menjelaskan media pembelajaran ada beberapa anak antusias dan ada juga beberapa anak yang kurang antusias. Misalnya guru memiliki empat media pembelajaran yang akan dijelaskan kepada anak bagaimana cara bermainnya. Yang pertama media mewarnai bacaan Assalamualaikum dengan menggunakan krayon. Dimana guru memberikan kebebasan kepada anak memilih warna apa saja yang akan dipakainya untuk mewarnai bacaan Assalamualaikum. Yang kedua bermain puzzle huruf hijaiyah, dimana anak menggurutkan huruf hijaiyah dari huruf (alif) sampai huruf (ya'), setelah mengurutkannya huruf hijaiyah lalu anak akan menyebutkan huruf hijaiyah yang ada dipuzzle. Yang ketiga bermain plastisin, disini guru mencontohkan dulu bagaimana cara membuat huruf hijaiyah dari plastisin, setelah itu anak bisa mencoba membuat huruf hijaiyah dari plastisin dan anak diberi kebebasan untuk memilih warna plastisinnya. 
Yang keempat menghubungkan garis putus-putus, dimana garis putus-putus tersebut akan menjadi bacaan Assalamualikum.

Setelah guru menjelaskan empat media pembelajaran, guru memberiakan instruksi kepada anak untuk mengerjakan tugas yang diberikan guru. Disini anak sudah ditentukan kelompoknya empat bermain puzzle, empat merwanai, empat bermain plastisin, dan empat menyambungakn garis putus-putus. Anak akan bergantian mengerjakan tugasnya supaya semua anak mengerjakan tugas yang diberikan oleh guru.

Peneliti melihat bahwa, ada beberapa anak yang menghindar mengerjakan tugas seperti mewarnai huruf hijayah. Dimana anak kurang antusias dengan media tersebut, dikarenakan mewarnai butuh waktu lama teralulu membosankan bagi anak. Biasanya ini terjadi pada beberapa anak laki-laki yang kurang antusias terhadap media mewarnai.

2. Mengajari anak lebih cepat dengan waktu relatife singkat

Mengajari anak lebih cepat dengan waktu relatife singkat, maksudnya jika guru menjelaskan pemebelajaran menggunakan kata-kata maka aka nada kesalah pemahaman bagi anak, tetapi dengan bantuan media pembelajaran guru akan mudah saat menjelaskan kepada anak tentang pembelajaran, dengan menggunakan media pembelajaran akan mempermudah guru dalam mempersingkat waktu belajar anak. Dengan begitu anak akan lebih cepat memahaminya.

Disentra Imtaq Peneliti melihat guru tidak hanya memberikan tugas tentang media pembelajaran saja tetapi hal yang paling penting disentra imtaq itu guru mengajari anak cara mengambil wudhu dan praktek sholat. Ketika anak memasuki kelas sentra Imtaq guru memberi tahu bahwa sebelum belajar anak praktek sholat dulu. Dimana guru mempraktekkan dulu cara mengambil wudhu, setelah itu anak mengikuti cara mengambil wudhu, kemudian anak laki-laki memakai sarung dan peci sedangkan anak peremuan memakai mukenah. Barulah anak-anak sholat bersama-sama yang menjadi imam anak laki-laki yang sudah dipilih oleh guru. Yang menjadi imam biasanya bergantian setiap anak yang masuk kekelas sentra Imtaq, maka anak laki-laki wajib mendapatkan giliran menjadi imam, karena disini guru mengajari anak untuk berani tampil didepan temannya.

Peneliti melihat disentra Imtaq itu kendala guru terletak dipraktek sholat, dimana praktek sholat membutuhkan waktu yang lama. Anak tidak hanya praktek sholat saja tetapi setelah praktek sholat anak diajak untuk berzikir, kemudian membaca doa kedua orang tua. Baru guru menjelaskan media pembelajaran kepada anak.

Dengan waktu yang singkat menggunakan media pembelajaran yang sederhana guru dengan singap menjelaskan media pembelajaran dan bagaimana cara bermainnya. Ketika anak mengerjakan tugasnya ada beberapa anak yang bisa menyelesaikan tugasnya dengan cepat dan ada anak yang lama menyelesaikan tugas yang diberikan oleh gurunya, karena setiap anak memiliki kemampuan yang berbeda-beda. 
3. Menambah daya pengertian dan ingatan

Menambah daya pengertian dan ingatan, maksudnya dengan menggunakan media pembelajaran akan mempermudahkan guru dalam memberikan pemahaman kepada anak pada saat proses belajar-bermain. Dimana anak akan mendapatkan pengalaman belajar serta ingatan anak akan bertahan lama terhadap pengetahuan yang didapatkannya.

Disentra Imtaq guru menggunakan media pembelajaran yang menarik bagi anak. Dimana dengan media yang menarik akan membantu anak untuk meningkatkan daya ingatnya, seperti media gambar cara mengambil wudhu dengan gambar tersebut anak dapat melihat dan mencoba bagaimana cara mengambil wudhu dengan benar, lalu media berbahan alam bagi anak seperti buah coklat asli, dengan buah coklat asli anak melihat bentuk, warna, isi dalam buah, mencicip buah coklat dan memengang buah coklat.

Dengan media yang asli anak mendapatkan pengalaman baru tentang buah coklat. Selanjutnya media puzzle huruf hijaiyah, dimana dengan puzzle tersebut anak tahu tentang bentuk huruf hijaiyah dan bacaannya. Media khaligrafi huruf hijaiyah, dimana media ini baru bagi anak dan guru ada tantangan guru dalam membuat media khaligrafi huruf hijaiyah ini, tetapi ketika dicobain kepada anak sebagian anak menyukainya, antusias anak sangat besar, banyak anak ikut mencobanya. Media plastisin dimana media ini paling banyak disenangi oleh anak, karena dengan plastisin anak bisa membuat huruf hijaiyah atau lainnya tergantung topic masing-masing.

Dari beberapa media pembelajaran yang digunakan guru bahwa dapat dikatakan dengan media tersebut guru sudah membantu anak dalam menambah daya ingat anak. Peneliti juga melihat bahwasannya guru disentra Imtaq TK Negeri Pembina 3 Pekenbaru sudah berinovasi dalam membuat media yang kreatif bagi anak agar antusias anak terhadap media guru lebih banyak.

4. Pembelajaran yang menyenangkan

Pembelajaran yang menyenangkan, yaitu pembelajaran yang proses kegiatan belajar anak tidak membosankan dengan kehadiran media pembelajaran akan dapat membantu anak dalam meningkatkan minat belajar anak dan membantu memotivasikan anak agar semangat mengikuti pembelajaran.

Peneliti melihat bahwa disentra imtaq masih ada beberapa anak merasa bosan saat pembelajaran berlangsung. Saat anak sudah mulai bosan dengan pembelajarannya guru mengajak anak untuk bertepuk tangan (anak soleh), bernyanyi bersama-sama, agar suasana yang membosankan itu menjadi suasana yang menyenangkan, dimana membantu anak juga dalam meningkatkan konsentrasi anak kembali. Dengan menggunakan media pembelajaran yang menarik, akan membantu guru dalam membuat suasana belajar yang menyenangkan. 
Maka dari itu Peneliti melihat juga bahwa guru sudah mulai membuat media pembelajaran yang menarik bagi anak dimana guru menggunakan bahan-bahan bekas, bahan alam dan bahan yang sering di jumpai anak.

Jadi anak bisa tau bahan apa saja yang di gunakan oleh guru dan dapat meningkatkan pengetahuannya, dimana bahan media pembelajaran guru yang anak tidak tau menjadi tau. Disitulah terjadi tanya jawab antara anak dan guru. Dengan begitu pembelajaran di kelas menjadi aktif karna adanya tanya jawab guru dan juga tidak lupa guru memberikan pujian terhadap anak yang bisa menjawab dan juga anak yang bisa menyampaikan pendapat dan idenya.

Sehingga pembelajaran yang awal nya membosankan menjadi menyenangkan karna adanya media menarik, tanya jawab dan pujian bagi anak. Jadi dengan begitu media pembelajaran yang di buat guru bisa tersampaikan dengan baik, menarik perhatian dan antusias anak terhadap media pembelajaran

\section{SIMPULAN DAN REKOMENDASI}

\section{Simpulan}

Penerapan media yang digunakan guru sebagai alat untuk mempermudah guru dalam menyampaikan tujuan pembelajaran, sehingga anak lebih mudah memahami dan mengingat pembelajaran agar dapat diterapkan saat praktek sholat. Media yang dibuat guru juga mampu mnembuat suasana belajar menjadi lebih menarik dan menyenangkan dan dengan begitu anak dapat menyelesaikan kegiatan yang diberikan oleh guru denga baik.

Dikelas sentra Imtaq guru sudah kreatif dalam pembuatan media pembelajaran. Dimana guru guru sudah menggunakan bahan-bahan bekas dan bahan alam. Dengan bahan bekas dan bahan alam anak dapat melihat langsung dan mengamati bahan-bahan media tersebut dan anak menemukan hal-hal yang baru yang didapatnya dalam mengamati bahan-bahan media pembelajaran.

\section{Rekomendasi}

Dalam upaya membuat media pembelajaran guru harus menciptakan mediamedia yang baru agar anak tidak merasa bosan. Media yang dibuat juga diharapkan untuk membantu anak dalam memahami pembelajaran, sehingga anak bisa melakukan kegiatan pembelajaran dan mencapai tujuan yang diinginkan.

\section{DAFTAR PUSTAKA}

Burhan, Bungin. 2005. Analisis Data Penelitian Kualitatif. Jakarta: Raja Grafindo Persada

Dewi, Kurnia, 2017. Pentingnya Media Pembelajaran Untuk Anak Usia Dini.

http://jurnal.radenfatah.ac.id/index.php/raudhatulathfal/article/view/1489. (tanggal akses 21 Maret 2018 20.00. WIB).

Fadilillah, M, 2017. Bermain dan Permainan. Jakarta: Kencana Prenadamedia Group 
Gunawan, Imam, 2013. Metode Penelitian Kualitatif Teori Dan Praktik. Jakarta: PT. Bumi Aksara

Jalinus, Nizwardi dkk, 2016, Media dan Sumber Pembelajaran. Jakarta: Kencana Prenadamedia Group

Khadijah, 2015. Media pembelajaran anak usia dini. Medan: Perdana Publishing

Latif, Mukhar dkk, 2013. Orientasi Baru Pendidikan Anak Usia Dini. Jakarta: Kencana Prenadamedia Group

Musifigon, 2012. Metodologi Penelitian Pendidikan. Jakarta: PT. Prestasi Pustakaraya

Sari, Yenda dkk, 2015. Penggunaan Media Pembelajaran Untuk Mengembangkan Kemampuan Motorik Halus Anak Usia Dini. http://download.portalgaruda.org/article.php?article $=372789 \& v a l=1555 \&$ tit le $=$ PENGGUNAAN $\% 20$ MEDIA $\% 20$ PEMBELAJARAN $\% 20 U N T U K \% 20$ MENGEMBANGKAN \%20KEMAMPUAN\%20MOTORIK $\% 20$ HALUS \%20ANAK\%20USIA\%20DINI. (tanggal akses 19 april 201805.37 WIB)

Sugiyono, 2008. Metode Penelitian Kuantitatif Kualitatif Dan R $\mho D$. Bandung: Alfabeta

Sunarti, Sri dkk, 2015. Analisis Penggunaan Media Pembelajaran Dalam Proses Belajar Mengajar Anak Usia 4-5 Tabun.

http://jurnal.untan.ac.id/index.php/ipdpd/article/download/9417/9304. (tanggal akses 29 Maret 2018 15.36 WIB

Suryana, Dadan, 2016. Pendidikan Anak Usia Dini Stimulusdan Aspek Perkembangan Anak. Jakarta: Kencana Prenadamedia Group

Susanto, Ahmad, 2017. Pendidikan Anak Usia Dini Konsep dan Teori. Jakarta: PT.Bumi Aksara

Yuanida, hana, tita Rosita, 2018. Outbound Berbasis Karakter Sebagai Media Pembelajaran Anak Usia Dini.

https://journal.ikipsiliwangi.ac.id/index.php/commedu/article/download/62. /19. (tanggal akses 28 Maret 2018 14.15 WIB). 